\title{
Sol-gel Synthesis and Characterization of Non-Substituted and Europium- Substituted Layered Double Hydroxides $\mathrm{Mg}_{3} / \mathrm{Al}_{1-\mathrm{x}} \mathbf{E u}_{\mathrm{x}}$
}

\author{
A. Smalenskaite ${ }^{1, *}$, S. Şen ${ }^{2}$, A. N. Salak ${ }^{3}$, M. G. S. Ferreira ${ }^{3}$, R. Skaudzius ${ }^{1}$, A. Katelnikovas ${ }^{4}$ and A. \\ Kareiva $^{1}$
}

\begin{abstract}
${ }^{1}$ Department of Inorganic Chemistry, Vilnius University, Naugarduko 24, LT-03225 Vilnius, Lithuania.; ${ }^{2}$ Department of Chemistry, Faculty of Arts and Sciences, Dumlupinar University, 43820 Kütahya, Turkey; ${ }^{3}$ Department of Materials and Ceramic Engineering/CICECO, University of Aveiro, 3810-193 Aveiro, Portugal and ${ }^{4}$ Department of Analytical and Environmental Chemistry, Vilnius University, Naugarduko 24, LT-03225 Vilnius, Lithuania
\end{abstract}

\begin{tabular}{l} 
A R T I C L E H I S T O R Y \\
\hline Received: November 15, 2016 \\
Revised: January 04,2017 \\
Accepted: January 26, 2017 \\
DOI: \\
10.2174/18779441076661702081546 \\
47
\end{tabular}

\begin{abstract}
The Mg/Al layered double hydroxides (LDHs) were successfully synthesized by novel aqueous sol-gel method. A series of europium-substituted layered double hydroxides $(\mathrm{Mg} / \mathrm{Al} / \mathrm{Eu} \mathrm{LDHs})$ were also synthesized using the same sol-gel processing. The $\mathrm{Eu}^{3+}$ substitution effects were investigated in the $\mathrm{Mg}_{3} / \mathrm{Al}_{1-\mathrm{x}} \mathrm{Eu}_{\mathrm{x}}$ system by changing the amount of $\mathrm{Eu}^{3+}$ in the crystal lattice from 0.05 to $10 \mathrm{~mol} \%$. The samples obtained were characterized by X-ray diffraction (XRD) analysis, Fourier Transform Infrared spectroscopy (FT-IR), thermogravimetric (TG) analysis, scanning electron microscopy (SEM) and fluorescence spectroscopy (FLS). The results revealed that europium enters into a hydrotalcite structure containing $\mathrm{Mg}^{2+}$ and $\mathrm{Al}^{3+}$ cations in the brucite-like layers.
\end{abstract}

Keywords: Layered double hydroxides, $\mathrm{Mg} / \mathrm{Al} / \mathrm{Eu}$, sol-gel processing, europium substitution effects, luminescent properties.

\section{INTRODUCTION}

Layered double hydroxides (LDHs) are compounds composed of positively charged brucite-like layers with an interlayer gallery containing charged compensating anions and water molecules. The metal cations occupy the centres of shared octahedral whose vertices contain hydroxide ions that connect to form infinite two-dimensional sheets [1-4]. With this structure the most know mineral is hydrotalcite, $\left[\mathrm{Mg}_{0.75} \mathrm{Al}_{0.25}(\mathrm{OH})_{2}\right]\left(\mathrm{CO}_{3}\right)_{0.125} \cdot 0.5 \mathrm{H}_{2} \mathrm{O}$. LDHs have a welldefined layered structure within nanometre scale $(0.3-3 \mathrm{~nm})$ of interlayer and contain important functional groups. After calcination at temperatures from 300 to $600{ }^{\circ} \mathrm{C}$, LDHs were converted to mixed metal oxides (MMO), which have the ability to recover the original layered structure [5-7]. LDHs have unique intrinsic advantages: their layer sizes are highly tunable and their constituents can be conveniently controlled and varied. LDHs, unlike common clay minerals such as montmorillonite, cannot swell automatically in water, and their delamination is much more difficult due to their high surface charge density as well as the strong attractions between adjacent nanosheets [8]. The formation and exploitation of new types of layered double hydroxide (LDH)/polymer NC hydrogels with high performance has also been investigated [9].

\footnotetext{
*Address correspondence to this author at the Department of Inorganic Chemistry, Faculty of Chemistry, Vilnius University, P.O. Box: LT-03225, Vilnius, Lithuania; Tel/Fax +370 (5) 219 3111, +370 (5) 233 0987; E-mail: aurelija.smalenskaite@gmail.com
}

One of the most important properties is the interlayer anion exchangeability, which endows LDHs the possibility of accommodating organic UV absorbers in the interlayer space [10]. Moreover, the LDHs have an $\mathrm{HCl}$ absorption capacity, and may be used as PVC thermal stabilizer [11].

In the positively charged brucite-like layers of LDHs, a fraction of the trivalent cations could be substituted by other same valence cations. Rare earth doped luminescent materials have drawn increasing attention as potential phosphor materials for use in optical devices [12-14].

Recently, considerable attention has been focused on incorporating rare earth ions into LDHs hosts to develop new functional materials, which resemble designed optical properties [15]. LDHs doped with $\mathrm{Tb}^{3+}$ ions in the brucite-like layers were prepared by a simple one-step co-precipitation method $[16,17]$. Nanosized LDHs doped with $\mathrm{Eu}^{3+}, \mathrm{Yb}^{3+}$, $\mathrm{Tb}^{3+}$ and $\mathrm{Nd}^{3+}$ were prepared through the microemulsion method [18]. The $\mathrm{Eu}^{3+}$ and $\mathrm{Nd}^{3+}$ were incorporated also into hydrocalumite and mayenite [19]. The $\mathrm{Zn} / \mathrm{Al} / \mathrm{Eu}$ and $\mathrm{Zn} / \mathrm{Al} / \mathrm{Dy} \mathrm{LDHs}$ were also reported as perspective and efficient luminescent materials [20-22]. Cerium-doped hydrotalcite-like precursors were also recently synthesized by co-precipitation method [23].

LDHs can be prepared by a variety of synthesis methods. However, the most common preparation technique is coprecipitation method starting from soluble salts of the metals. Sol-gel synthesis route for mixed metal oxides and related 
compounds have some benefits over other methods such as simplicity, synthesis at low temperatures, effectiveness, suitability for different systems and cost efficiency [24-27].

The main aim of this study was to investigate $\mathrm{Eu}^{3+}$ substitution effects in the $\mathrm{Mg}_{/} \mathrm{Al}_{1-\mathrm{x}} \mathrm{Eu}_{\mathrm{x}}$ systems (the $\mathrm{Eu}^{3+}$ concentration in the crystal lattice was changed from 0.05 to $10 \mathrm{~mol} \%$ ) fabricated for the first time to the best of our knowledge by sol-gel synthesis route. The luminescent properties of $\mathrm{Mg}_{3} / \mathrm{Al}_{1-\mathrm{x}} \mathrm{Eu}_{\mathrm{x}} \mathrm{LDH}$ samples were also investigated.

\section{MATERIALS AND METHOD}

Aluminium (III) nitrate nonahydrate $\left(\mathrm{Al}\left(\mathrm{NO}_{3}\right)_{3} \cdot 9 \mathrm{H}_{2} \mathrm{O}\right)$, 98.5\% (Hempur); magnesium (II) nitrate hexahydrate $\left(\mathrm{Mg}\left(\mathrm{NO}_{3}\right)_{2} \bullet 6 \mathrm{H}_{2} \mathrm{O}\right), 99 \%$ (Hempur); europium (III) nitrate pentahydrate $\left(\mathrm{Eu}\left(\mathrm{NO}_{3}\right)_{3} \cdot 5 \mathrm{H}_{2} \mathrm{O}, 99.9 \%\right.$ (Sigma-Aldrich); ethylene glycol $\left(\mathrm{C}_{2} \mathrm{H}_{6} \mathrm{O}_{2}\right), 99.5 \%$ (Roth); citric acid $\left(\mathrm{C}_{6} \mathrm{H}_{8} \mathrm{O}_{7}\right)$, 99.5\% (Hempur).

$\mathrm{X}$-ray diffraction patterns were recorded using MiniFlex II diffractometer (Rigaku) using a primary beam $\mathrm{Cu} \mathrm{K} \alpha$ radiation $(\lambda=1.541838 \AA)$. The $2 \theta$ angle of the diffractometer was gradated from 8 to $80^{\circ}$ in steps of $0.02^{\circ}$, with the measuring time of $0.4 \mathrm{~s}$ per step. FT-IR analysis of compounds was conducted using Perkin-Elmer FTIR spectrometer. All spectra were recorded at ambient temperature in the range of $4000-400 \mathrm{~cm}-1$. Thermal analysis was carried out using a simultaneous thermal analyzer 6000 (Perkin-Elmer) in air atmosphere at scan rate of $10{ }^{\circ} \mathrm{C} / \mathrm{min}$ and the temperature range from $30{ }^{\circ} \mathrm{C}$ up to $900{ }^{\circ} \mathrm{C}$. Excitation and emission spectra were recorded on an Edinburg Instruments FLS 900 spectrometer. The morphology of particles was investigated using a scanning electron microscope (SEM) Hitachi SU-70.

\section{EXPERIMENTAL:}

The $\mathrm{Mg}_{3} / \mathrm{Al}_{1-\mathrm{x}} \mathrm{Eu}_{\mathrm{x}} \mathrm{LDH}$ samples were synthesised by the sol-gel method from the solution of metal nitrates $\mathrm{Mg}\left(\mathrm{NO}_{3}\right)_{2} \cdot 6 \mathrm{H}_{2} \mathrm{O}, \mathrm{Al}\left(\mathrm{NO}_{3}\right)_{3} \cdot 9 \mathrm{H}_{2} \mathrm{O}$ and $\mathrm{Eu}\left(\mathrm{NO}_{3}\right)_{3} \cdot 6 \mathrm{H}_{2} \mathrm{O}$, dissolved in $50 \mathrm{ml}$ of distilled water. Secondly, $0.2 \mathrm{M}$ citric acid was added and obtained solution was stirred for $1 \mathrm{~h}$ at $80^{\circ} \mathrm{C}$. Next, $2 \mathrm{ml}$ of ethylene glycol have been added to the resulted mixture with continued stirring at $150{ }^{\circ} \mathrm{C}$ until the complete evaporation of solvent. The obtained gel was dried at $105^{\circ} \mathrm{C}$ for $24 \mathrm{~h}$. The mixed metal oxides were obtained by heating the gels at $650{ }^{\circ} \mathrm{C}$ for $4 \mathrm{~h}$. The $\mathrm{Mg}_{3} / \mathrm{Al}_{1-\mathrm{x}} \mathrm{Eu}_{\mathrm{x}} \mathrm{LDH}$ specimens were obtained by reconstruction of MMO powders in water at $50{ }^{\circ} \mathrm{C}$ for $6 \mathrm{~h}$ under stirring. For comparison, the $\mathrm{Mg} / \mathrm{Al}$ hydrotalcite was also synthesized and analysed.

\section{RESULTS AND DISCUSSIONS:}

The synthesized $\mathrm{Mg} / \mathrm{Al}$ and $\mathrm{Mg} / \mathrm{Al} / \mathrm{Eu} \mathrm{LDHs}$ were characterized by XRD analysis (Figs. 1-3). Evidently, only amorphous $\mathrm{Mg}-\mathrm{Al}-\mathrm{O}$ gel has formed during the initial stage of sol-gel processing of LDHs (Fig. 1). After heat-treatment of Mg-Al-O precursor gel at $650{ }^{\circ} \mathrm{C}$, a high crystalline mixed-metal oxide (MMO) has formed. The obtained MMO powdered samples were treated in water at $50{ }^{\circ} \mathrm{C}$ for $6 \mathrm{~h}$ under stirring. The XRD patterns of obtained specimens confirmed the formation of monophasic Mg/Al LDH during the "reconstruction" process in water. Three characteristic peaks of hydrotalcite at $2 \theta$ of about $10^{\circ}(003), 23^{\circ}(006)$ and $35^{\circ}$ (009) were observed in sol-gel derived LDH samples. Moreover, two very important reflections for LDHs are also clear- ly seen at about $60.2^{\circ}(110)$ and $61.5^{\circ}(113)$. Based on the XRD pattern, there are slight shifts of characteristic basal plane $d$ (003) related to the existing of different anions in the interlayer regions. The carbonate acts as a balancing anion because of its high affinity in the hydroxide layer over nitrate anions. In the simplest case, anion exchange is achieved by stirring an aqueous solution of the LDH precursor with a large excess of the anion salt. LDHs containing carbonate anions within the host material are less susceptible to anion exchange reactions due to high selectivity for this anion.

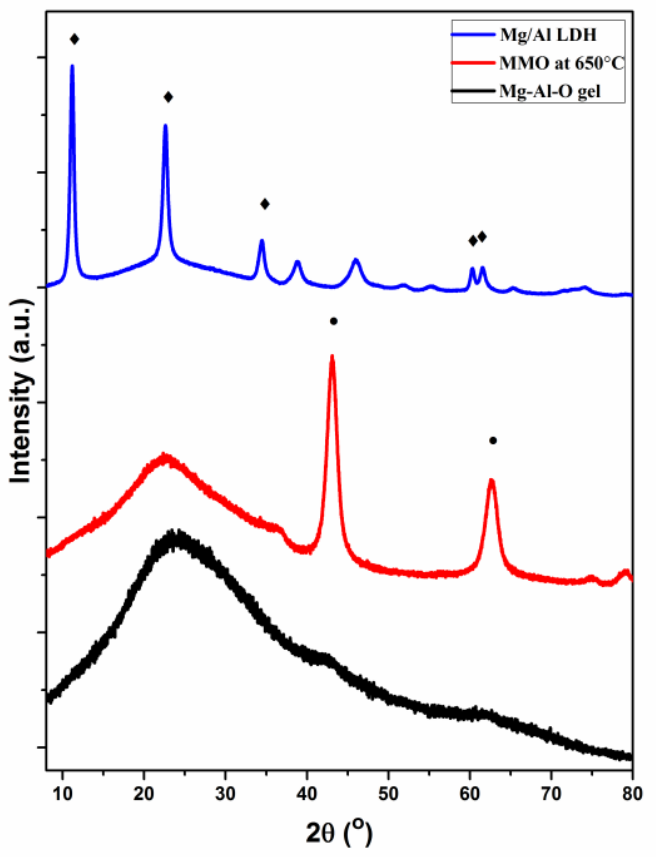

Fig. (1). XRD patterns of Mg-Al-O precursor gel, mixed-metal oxide obtained at $650{ }^{\circ} \mathrm{C}$ and sol-gel derived $\mathrm{Mg} / \mathrm{Al} \mathrm{LDH}$. The crystalline phases are marked: $\mathrm{MgO}-\bullet$ and hydrotalcite $-\bullet$.

All synthesized europium-substituted (1-10 mol\%) MgAl-O gels also were amorphous powders to compare with $\mathrm{Mg} / \mathrm{Al} \mathrm{LDH}$ (Fig. 1). According to the XRD patterns presented in Fig. 2 the heat-treated $\mathrm{Mg} / \mathrm{Al} / \mathrm{Eu}$ gels resulted in high crystalline MMO samples. The mixed-metal oxides transformed fully to LDH structures independent on the $\mathrm{Eu}$ substitutional level (see Fig. 3). The observed shift of the (110) reflections displacement signal toward lower values of $2 \theta$ containing different concentration of $\mathrm{Eu}^{3+}$ can be an evidence of isomorphic incorporation of lanthanide ion in LDH. The calculated d values for (110) peak (for $1 \mathrm{~mol} \% \mathrm{Eu}^{3+}$ $1.5288 \AA ; 5 \mathrm{~mol} \% \mathrm{Eu}^{3+} 1.5302 \AA ; 7.5 \mathrm{~mol} \% \mathrm{Eu}^{3+} 1.5330 \AA$ and $10 \mathrm{~mol} \% \mathrm{Eu}^{3+} 1.5359 \AA$ ), compared with non-doped $\mathrm{Mg} / \mathrm{Al} \mathrm{d}(110)=1.5274 \AA$ monotonically increased by increasing the $\mathrm{Eu}^{3+}$ concentration. The monophasic $\mathrm{Mg} / \mathrm{Al} / \mathrm{Eu}$ LDHs were obtained with amount of Eu less than $5 \mathrm{~mol} \%$. With increasing concentration of europium till $7.5 \mathrm{~mol} \%$ the negligible amount of side $\mathrm{Eu}(\mathrm{OH})_{3}$ phase has formed. The formation of $\mathrm{Eu}(\mathrm{OH})_{3}$ is mainly due to the larger ionic radius of $\mathrm{Eu}^{3+}$ ions $(1.08 \AA)$ in comparison of ionic radius of $\mathrm{Al}^{3+}$ ions $(0.53 \AA)$. The $\mathrm{Eu}^{3+}$ ions taking up the octahedral positions of $\mathrm{Al}^{3+}$ ions led to the deformation of crystal lattice, and the excess $\mathrm{Eu}^{3+}$ ions in high basic condition crystallized as $\mathrm{Eu}(\mathrm{OH})_{3}$. 


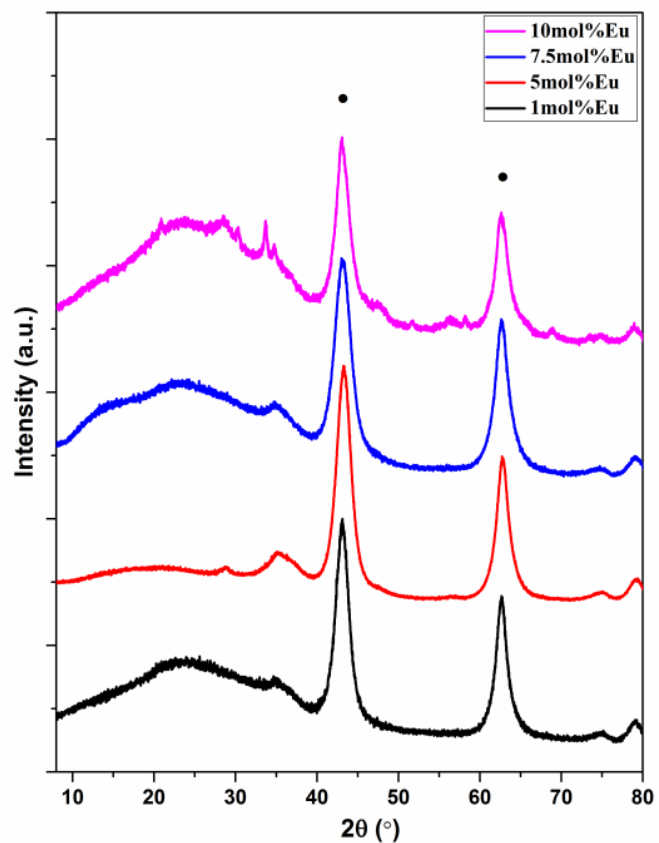

Fig. (2). XRD patterns of $\mathrm{Mg} / \mathrm{Al} / \mathrm{Eu} 1-10 \mathrm{~mol} \%$ gels calcined at $650{ }^{\circ} \mathrm{C}$. The crystalline phase is marked: $\mathrm{MgO}-\bullet$.

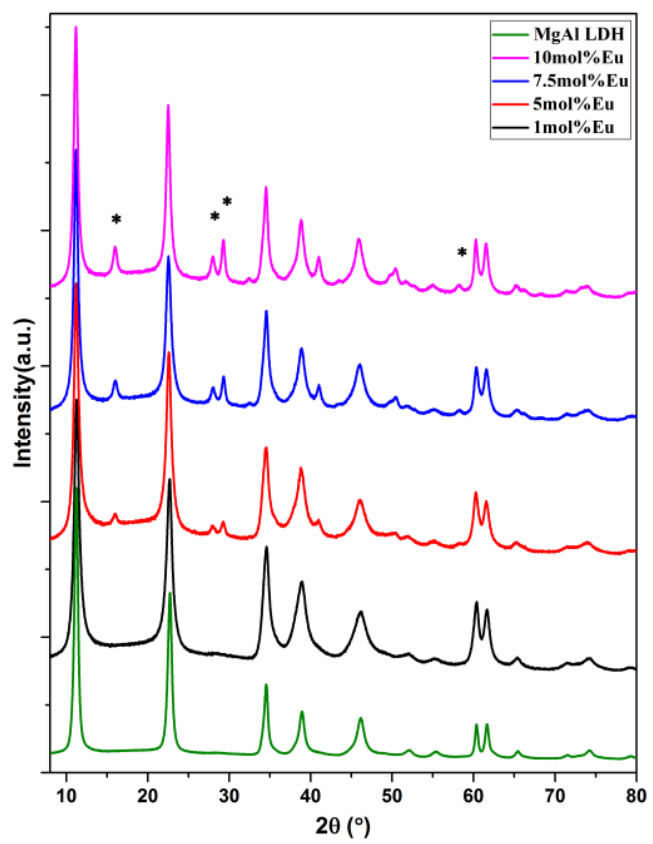

Fig. (3). XRD patterns of synthesized by sol-gel method $\mathrm{Mg} / \mathrm{Al} / \mathrm{Eu} 1-10 \mathrm{~mol} \%$ LDHs. The $\mathrm{Eu}(\mathrm{OH})_{3}$ phase is marked: *.

Thus, these results confirmed once again that highly crystalline LDHs could be synthesized during hydroxylation solgel derived crystalline MMO samples in aqueous media. At high temperature of calcination, crystalline mixed oxide and partial changes result in the local structure of the $\mathrm{M}_{\mathrm{III}}$ cations. A partial regeneration of the layered phase takes place which is characterized by different composition and morphology.
The XRD patterns of the synthesized LDHs contain very sharp diffraction lines attributable only to LDH crystalline phase at low concentration of europium. Interestingly, the formation of sol-gel based LDHs depends on the concentration of europium in the samples.

FT-IR spectra of $\mathrm{Mg} / \mathrm{Al}$ and $\mathrm{Mg} / \mathrm{Al} / \mathrm{Eu} \mathrm{LDH}$ samples in the region of 4000-500 $\mathrm{cm}^{-1}$ are shown in Fig. 4. The spectra recorded for all samples are very similar to each other without any important differences. The absorption bands observed at around $3500-3000 \mathrm{~cm}^{-1}$ correspond to the stretching vibrations of hydroxyl $(-\mathrm{OH})$ groups from the hydroxyl layers and from intercalated and externally adsorbed water molecules [28]. The broad band identified at $2974 \mathrm{~cm}^{-1}$ is assigned to the stretching mode of hydroxyl groups hydrogen-bonded to interlayer carbonate anions. The presence of adsorbed molecular water was confirmed by the medium intensity band at $1629 \mathrm{~cm}^{-1}$. The strong absorption band visible at $1353 \mathrm{~cm}^{-1}$ is attributed to the asymmetric vibrations modes of $\mathrm{CO}_{3}{ }^{2-}$. The absorption bands observed at $613 \mathrm{~cm}^{-1}$ can be ascribed to the metal-oxygen $\mathrm{M}^{2+}-\mathrm{O}$ and $\mathrm{M}^{3+}-\mathrm{O}$ stretching mode.

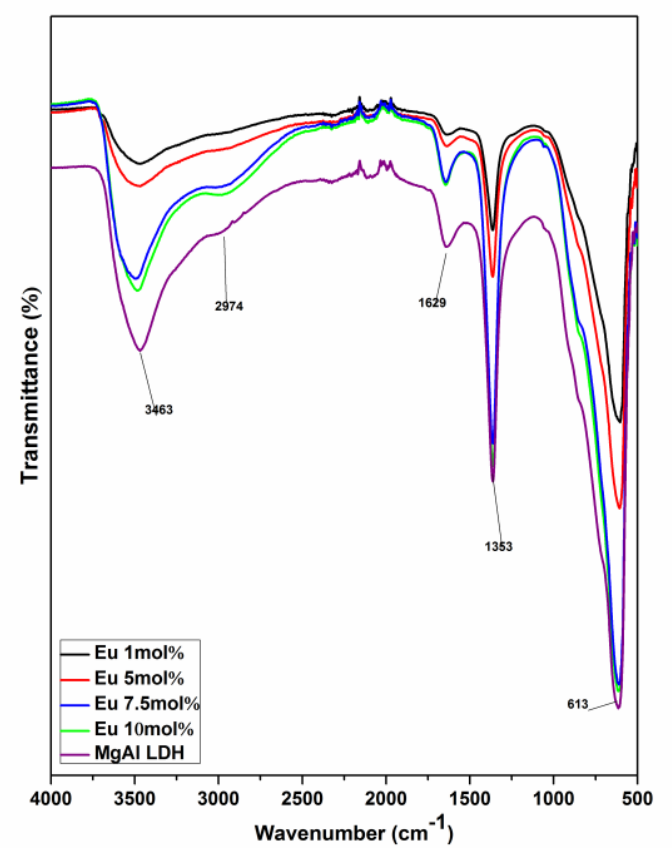

Fig. (4). FT-IR spectra of $\mathrm{Mg} / \mathrm{Al}$ and $\mathrm{Mg} / \mathrm{Al} / \mathrm{Eu} 1-10 \mathrm{~mol} \%$ LDHs.

The TG-DCS curves of synthesised $\mathrm{Mg} / \mathrm{Al}$ and $\mathrm{Mg} / \mathrm{Al} / \mathrm{Eu} 10 \mathrm{~mol} \%$ LDHs are shown in Figs. 5 and 6, respectively. As seen, the thermal behaviour of synthesized LDH is not dependent on the europium substitution in the structure. The initial mass loss about $\sim 15 \%$ was observed in the temperature range of $30-200{ }^{\circ} \mathrm{C}$ for the $\mathrm{Mg} / \mathrm{Al}$ and $\mathrm{Mg} / \mathrm{Al} / \mathrm{Eu}$ LDHs prepared by sol-gel method. These changes in mass are due to the collapse of interlayer and evolution of adsorbed water. The main decomposition of LDH samples occurs via one step in the temperature range of $200-600^{\circ} \mathrm{C}$ (the mass loss $\sim 45-48 \%$ ). The second mass loss step is due to the dihydroxylation and decomposition of the impurities of interlayer ionic carbonate. The observed thermal effects in DSC 
curves support the results obtained from TG measurements. Above $600{ }^{\circ} \mathrm{C}$ the brucite-type structure collapses and a solid solution of mixed spinel $\left(\mathrm{MgAl}_{2} \mathrm{O}_{4}\right)$ and $\mathrm{MgO}$, or $\mathrm{Al}_{2} \mathrm{O}_{3}$ and $\mathrm{MgO}$ is formed.

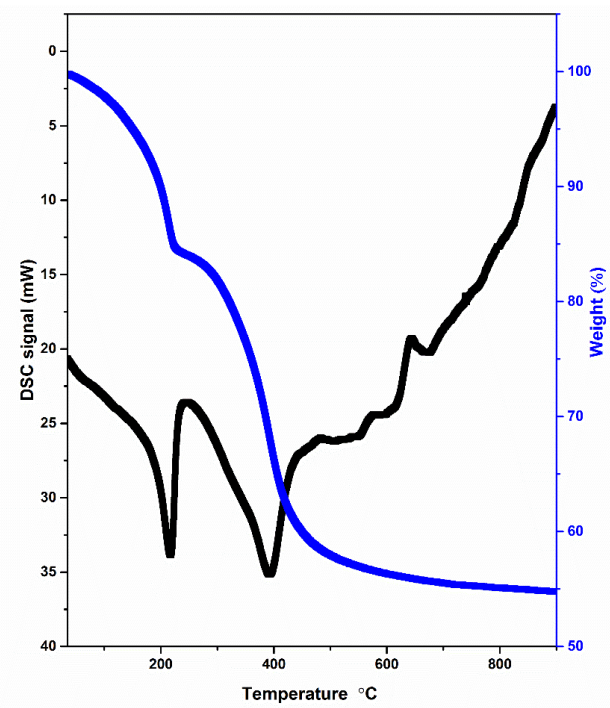

Fig. (5). TG-DSC curves of the Mg/Al LDH.

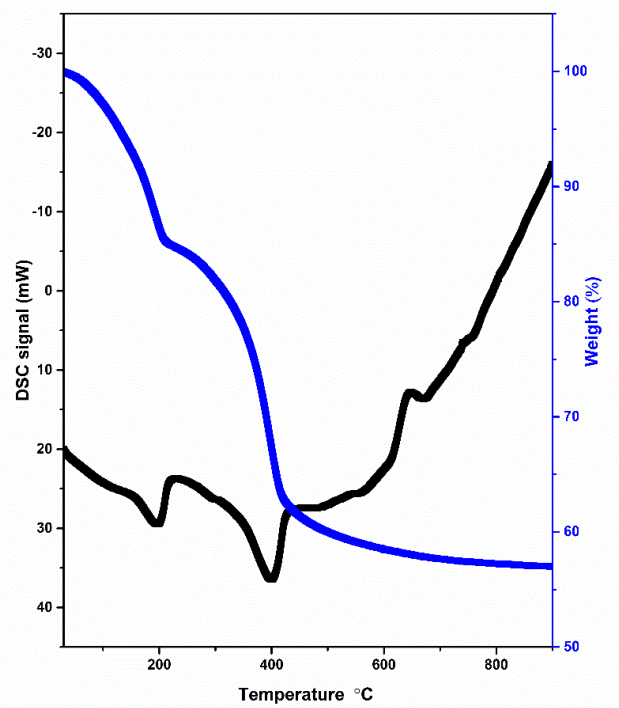

Fig. (6). TG-DSC curves of the $\mathrm{Mg} / \mathrm{Al} / \mathrm{Eu} 10 \mathrm{~mol} \% \mathrm{LDH}$.

The microstructure for the synthesized LDH samples was determined from the SEM micrographs. The SEM micrographs of calcined $\mathrm{Mg} / \mathrm{Al}$ precursor and sol-gel derived $\mathrm{LDH}$ sample are shown in Fig. 7. The mixed metal oxide obtained by calcination of $\mathrm{Mg}-\mathrm{Al}-\mathrm{O}$ gel at $650{ }^{\circ} \mathrm{C}$ is composed of the network of spherical nanoparticles varying in size from approximately 2 to $5 \mu \mathrm{m}$. A layered double structure was recovered after reconstruction procedure in water, showing the formation of plate-like particles with hexagonal shape (Fig. 7b). The surface morphology of $\mathrm{Eu}^{3+}$-substituted LDH samples is very similar for all specimens independent of the substitutional level. Fig. 8 shows the representative SEM micrographs of sol-gel synthesized $\mathrm{Mg} / \mathrm{Al} / \mathrm{Eu} \quad 1 \mathrm{~mol} \%$ and $\mathrm{Mg} / \mathrm{Al} / \mathrm{Eu} 10 \mathrm{~mol} \%$ samples. As seen, small fibrous plate-like particles with hexagonal structure are aggregated as in the case of non-substituted LDH sample. So, all sol-gel derived $\mathrm{Mg} / \mathrm{Al} / \mathrm{Eu} \mathrm{LDHs}$ consist of the larger hexagonally shaped particles varying in size from approximately 250 to $500 \mathrm{~nm}$. The surface morphological features of sample with highest europium content are more pronounced consisting of hexagonally shaped nanostructures in LDHs. Finally, the complete regeneration LDHs samples from MMO in aqueous media has been observed.

a)

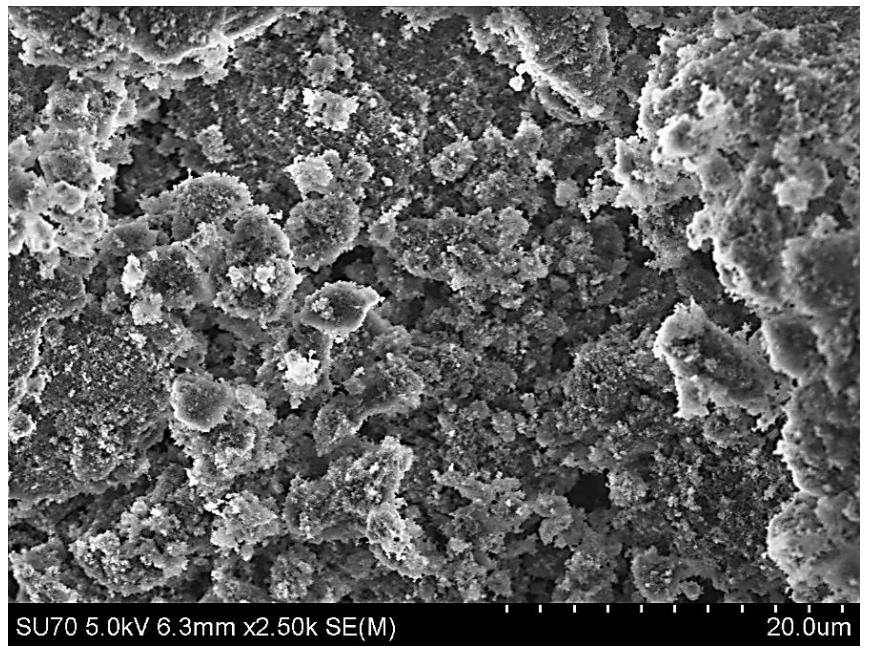

b)

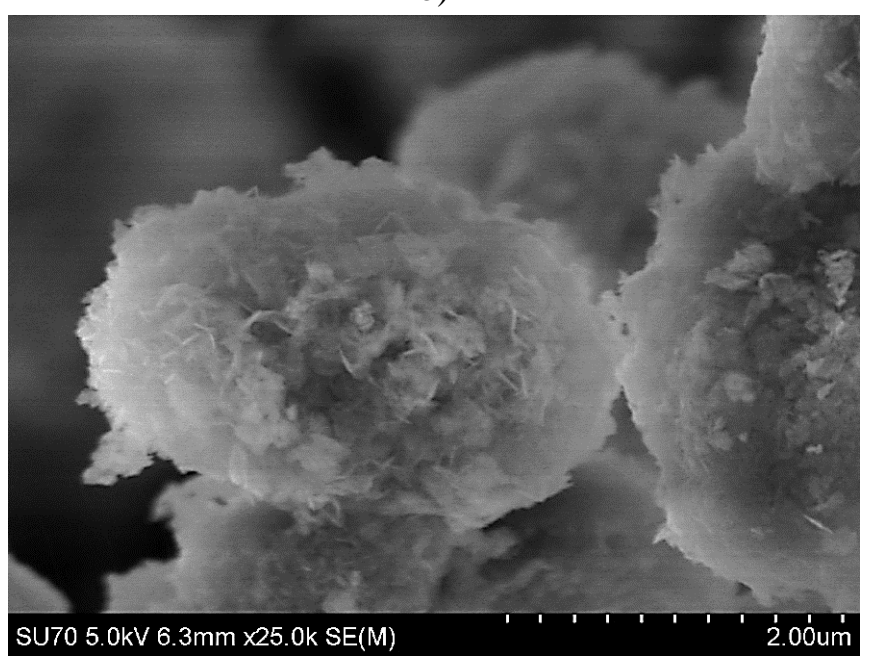

Fig. (7). SEM micrographs of MMO (a) and sol-gel synthesized $\mathrm{Mg} / \mathrm{Al} \mathrm{LDH}$ (b).

The emission spectra obtained at room temperature of all the $\mathrm{Mg} / \mathrm{Al} / \mathrm{Eu} \mathrm{LDH}$ samples under excitation at $320 \mathrm{~nm}$ are presented in Fig. 9. As seen, all samples share similar emission profiles. The emission spectra of $\mathrm{Mg} / \mathrm{Al} / \mathrm{Eu} \mathrm{LDHs}$ shows three main emissions in the wavelength range of 500 $740 \mathrm{~nm}$. In all spectra, the emission bands characteristic for ${ }^{5} \mathrm{D}_{0}{ }^{-}{ }^{7} \mathrm{~F}_{\mathrm{J}}(\mathrm{J}=1,2,3,4)$ transitions of $\mathrm{Eu}^{3+}$ ions were observed. The emission peaks are referred to the typical three ${ }^{5} \mathrm{D}_{0} \rightarrow{ }^{7} \mathrm{~F}_{1}$ $(591 \mathrm{~nm}){ }^{5} \mathrm{D}_{0} \rightarrow{ }^{7} \mathrm{~F}_{2}(615 \mathrm{~nm})$ and ${ }^{5} \mathrm{D}_{0} \rightarrow{ }^{7} \mathrm{~F}_{4}(703)$ transitions of $\mathrm{Eu}^{3+}$ ion. The emission due to ${ }^{5} \mathrm{D}_{0} \rightarrow{ }^{7} \mathrm{~F}_{2}$ transition is the strongest, indicating that $\mathrm{Eu}^{3+}$ ions occupy a low-symmetry 
site. ${ }^{5} \mathrm{D}_{0} \rightarrow{ }^{7} \mathrm{~F}_{2}$ transition called as a hypersensitive transition. This can be caused by the addition of another molecule (for example, a competitive ligand) by a variation of the ionic strength of the solution (addition of a salt), by a variation of the polarity of the solvent (addition of another solvent), or by a variation of the $\mathrm{pH}$ value of the solution (addition of an acid or a base) when working in aqueous solutions. The presence of the low-symmetry structure containing the $\mathrm{Eu}^{3+}$ can only be observed in the nanocrystal line products, the results allow to exclude the adsorption of $\mathrm{Eu}^{3+}$ on the surface of LDHs [29]. When $\mathrm{Eu}^{3+}$ ions occupy the sites with inversion symmetry, the ${ }^{5} \mathrm{D}_{0} \rightarrow{ }^{7} \mathrm{~F}_{1}$ transition, typical magnetic dipole transition, should be relatively dominant; while, if there is no inversion symmetry at the sites of $\mathrm{Eu}^{3+}$ ions, ${ }^{5} \mathrm{D}_{0} \rightarrow{ }^{7} \mathrm{~F}_{2}$ transition should be relatively dominant [30]. It is clear that the photoluminescence intensity in the $\mathrm{Mg} / \mathrm{Al} / \mathrm{Eu}$ $\mathrm{LDH}$ phase increases with increasing the $\mathrm{Eu}^{3+}$ concentration, and reaches the maximum when the concentration of $\mathrm{Eu}^{3+}$ is $7.5 \%$. With further increasing amount of europium the intensity of emission decreases due to the concentration quenching. As the concentration of $\mathrm{Eu}^{3+}$ increases, the distances between $\mathrm{Eu}^{3+}$ ions in the layers will be shortened, which dramatically increases the interaction of ions and causes serious concentration quenching. This fact suggested that $\mathrm{Eu}^{3+}$ ions replaced $\mathrm{Al}^{3+}$ in the host lattice.
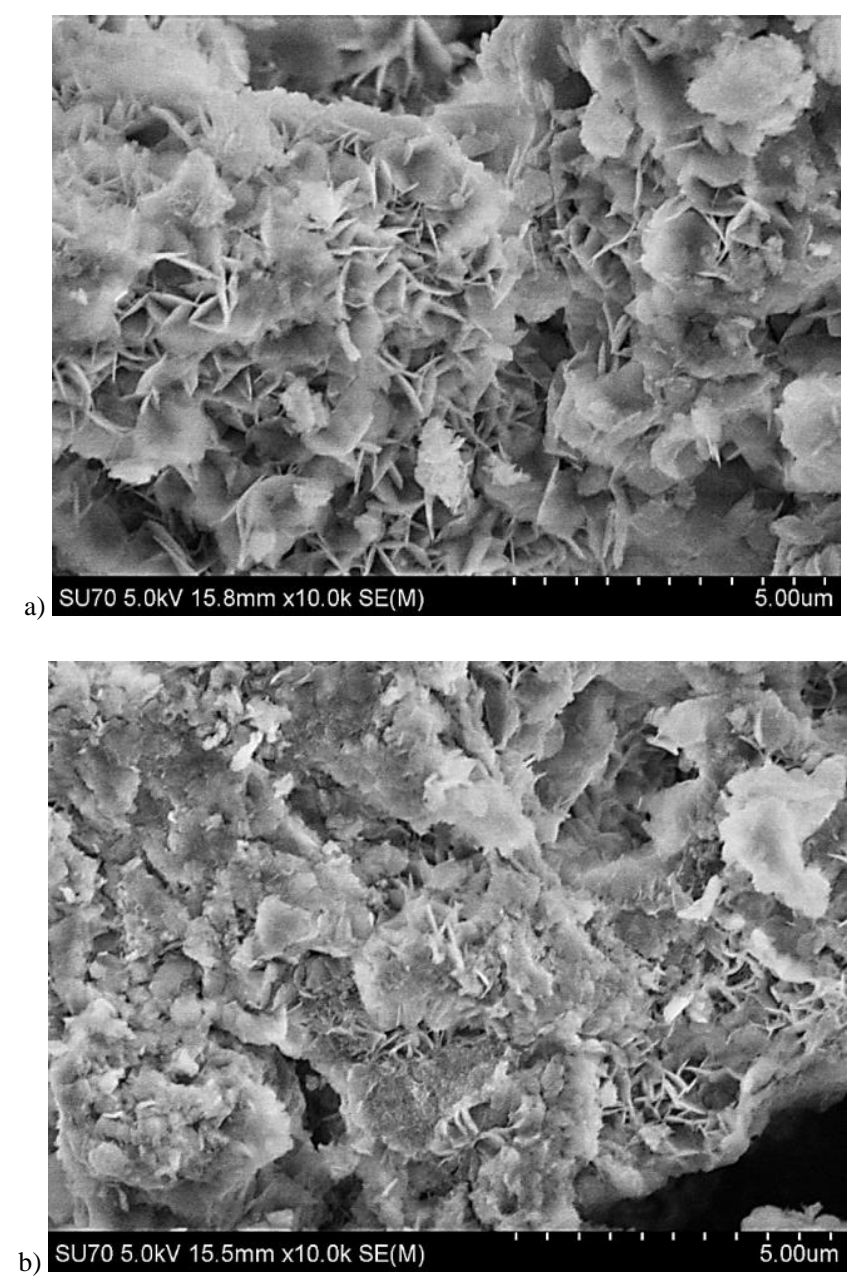

Fig. (8). SEM micrographs of $\mathrm{Mg} / \mathrm{Al} / \mathrm{Eu} 1 \mathrm{~mol} \%$ (a) and $\mathrm{Mg} / \mathrm{Al} / \mathrm{Eu}$ $10 \mathrm{~mol} \%$ (b) LDHs.

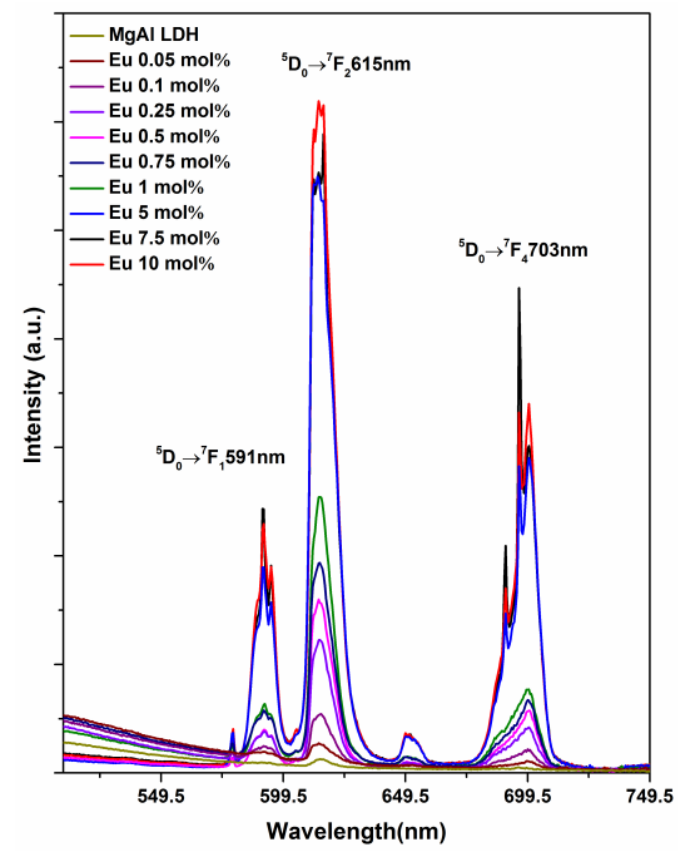

Fig. (9). Photoluminescence emission spectra of $\mathrm{Mg} / \mathrm{Al} / \mathrm{Eu}^{3+} \mathrm{LDHs}$ $\left(\lambda_{\mathrm{ex}}=320 \mathrm{~nm}\right)$.

\section{CONCLUSION}

The $\mathrm{Mg} / \mathrm{Al} /$ layered double hydroxides (LDHs) were successfully synthesized by novel aqueous sol-gel method. In the sol-gel processing route, the LDHs were obtained after the decomposition of Mg-Al-O precursor gels and following "reconstruction" of intermediate crystalline MMO samples in aqueous media. The same synthesis parameters were successfully applied for the synthesis of europium-substituted $\mathrm{Mg} / \mathrm{Al} / \mathrm{Eu}^{3+} 0.05-10 \mathrm{~mol} \% \mathrm{LDHs}$. Interestingly, the formation of sol-gel based $\mathrm{Mg} / \mathrm{Al} / \mathrm{Eu}^{3+} \mathrm{LDHs}$ depends slightly on the concentration of europium used in the samples. With increasing the concentration of europium till $7.5 \mathrm{~mol} \%$ the negligible amount of side $\mathrm{Eu}(\mathrm{OH})_{3}$ phase has formed. The typical LDH microstructure was determined from the SEM micrographs. The sol-gel synthesized LDH samples consisted of hexagonally shaped particles varying in size from approximately 250 to $500 \mathrm{~nm}$. The luminescence of $\mathrm{Mg} / \mathrm{Al} / \mathrm{Eu}^{3+} \mathrm{LDHs}$ was also investigated in this study. The emission peaks are referred to the typical three ${ }^{5} \mathrm{D}_{0} \rightarrow{ }^{7} \mathrm{~F}_{1}$ $(591 \mathrm{~nm})$ and ${ }^{5} \mathrm{D}_{0} \rightarrow{ }^{7} \mathrm{~F}_{2}(615 \mathrm{~nm}){ }^{5} \mathrm{D}_{0} \rightarrow{ }^{7} \mathrm{~F}_{4}(703 \mathrm{~nm})$ transitions of $\mathrm{Eu}^{3+}$ ion. It was also suggested from these results, that $\mathrm{Eu}^{3+}$ replaced $\mathrm{Al}^{3+}$ ions in the host lattice.

\section{CONFLICT OF INTEREST}

The authors confirm that this article content has no conflict of interest.

\section{ACKNOWLEDGEMENTS}

The work has been performed as part of the TUMOCS project. This project has received funding from the European Union's Horizon 2020 research and innovation programme under the Marie Skłodowska-Curie grant agreement No 645660. The financial support of P2020 COMPETE and FCT-Portugal through project POCI-01-0145-FEDER- 


\section{6 - PTDC/CTM-NAN/2418/2014 (NANOCONCOR)} is also acknowledged.

\section{REFERENCES}

[1] Klemkaite, K.; Prosycevas, I.; Taraskevicius, R.; Khinsky, A.; Synthesis and characterization of layered double hydroxides with different cations $(\mathrm{Mg}, \mathrm{Co}, \mathrm{Ni}, \mathrm{Al})$, decomposition and reformation of mixed metal oxides to layered structures Kareiva A. Centr Eur. J. Chem., 2011, 9, 275-282.

[2] Bi, X.; Zhang, H.; Dou, L. Layered Double Hydroxide-Based Nanocarriers for Drug Delivery. Pharmaceutics, 2014, 6, 298-332.

[3] Wu, J.; Ren, Z.Y.; Du, S.C.; Kong, L.J.; Liu, B.W.; Xi, W.; Zhu, J.Q.; Fu, H.G. Layered Double Hydroxide-Based Nanocarriers for Drug Delivery. Pharmaceutics Nano Res., 2016, 9, 713-725.

[4] Rives, V. Layered Double Hydroxides: Present and Future. Nova Science Publishers, New York, 2001.

[5] Klemkaite, K.; Khinsky, A.; Kareiva, A. Reconstitution effect of $\mathrm{Mg} / \mathrm{Ni} / \mathrm{Al}$ layered double hydroxide. Mater Lett., 2011, 65, 388391.

[6] Cosano, D.; Esquinas, C.; Jimenez-Sanchidrian, C.; Ruiz, J.R. Use of Raman spectroscopy to assess the efficiency of $\mathrm{MgAl}$ mixed oxides in removing cyanide from aqueous solutions. Appl. Surf. Sci., 2016, 3644, 28-433.

[7] Ivanov, M.; Klemkaite, K.; Khinsky, A.; Kareiva, A.; Banys, J. Dielectric and Conductive Properties of Hydrotalcite. Ferroelectrics, 2011, 417, 136-142.

[8] Hu, Z.; Chen, G. Aqueous dispersions of layered double hydroxide/ polyacrylamide nanocomposites: preparation and rheology. J. Mater. Chem. A, 2014, 2, 13593.

[9] Hu, Z.; Chen, G. Novel nanocomposite hydrogels consisting of layered double hydroxide with ultrahigh tensibility and hierarchical porous structure at low inorganic content. Adv. Mater, 2014, 26, 5950.

[10] Cao, T.; Xu, K.; Chen, G.; Guo, C. Poly (ethylene terephthalate) nanocomposites with a strong UV-shielding function using UVabsorber intercalated layered double hydroxides. RSC Advances, 2013, 3, 6282 .

[11] Liua, J.; Chena, G.; Yang, J. Preparation and characterization of poly (vinyl chloride)/layered double hydroxide nanocomposites with enhanced thermal stability. Polymer, 2008, 49, 3923.

[12] Stanulis, A.; Katelnikovas, A.; Enseling, D.; Dutczak, D.; Sakirzanovas, S.; Van Bael, M.; Hardy, A.; Kareiva, A.; Jüstel, T. Luminescence properties of $\mathrm{Sm}^{3+}$ - doped alkaline earth ortho-stannates. Opt. Mater, 2014, 36, 1146-1152.

[13] Skaudzius, R.; Juestel, T.; Kareiva, A. Study of $\mathrm{Eu}^{3+}$ and $\mathrm{Tm}^{3+}$ substitution effects in sol-gel fabricated calcium hydroxyapatite. Mater Chem. Phys., 2016, 170, 229-238.

[14] Binnemans, K. Lanthanide-based luminescent hybrid materials. Chem. Rev., 2009, 109(9), 4283-4374.

[15] Gunawan, P.; Xu, R. Lanthanide-doped layered double hydroxides intercalated with sensitizing anions: efficient energy transfer between host and guest layers. J. Phys. Chem. C, 2009, 113, 1720617214 .
[16] Vicente, P.; Perez-Bernal, M.E.; Ruano-Casero, R.J.; Ananias, D.; Paz, P.A.A.; Rocha, J.; Rives, V. Luminescence properties of lanthanide-containing layered double hydroxides. Micropor. Mezopor. Mater., 2016, 226, 209-220.

[17] Posati, T.; Costantino, F.; Latterini, L.; Nocchetti, M.; Paolantoni, M.; Tarpani, L. New insights on the incorporation of lanthanide ions into nanosized layered double hydroxides. Inorg. Chem., 2012, $51,13229-13236$.

[18] Domiguez, M.; Perez-Bernal, M.E.; Ruano-Casero, R.; Barriga, C.; Rives, V.; Ferreira, R.A.S.; Carlos, L.D.; Rocha, J. Multiwavelength luminescence in lanthanide-doped hydrocalumite and mayenite. Chem. Mater., 2011, 23, 1993-2004.

[19] Zhang, Z.; Chen, G.M.; Liu, J.G. Tunable photoluminescence of europium-doped layered double hydroxides intercalated by coumarin-3-carboxylate. RSC Adv., 2014, 4, 7991-7997.

[20] Gao, X.R.; Lei, L.X.; Kang, L.W.; Wang, Y.Q.; Lian, Y.W.; Jiang, K.L. Synthesis, characterization and optical properties of a red organic-inorganic phosphor based on terephthalate intercalated Zn/Al/Eu layered double hydroxide. J. All Compd., 2014, 585, 703707.

[21] Vargas, D.R.M.; Oviedo, M.J.; Lisboa, F.D.; Wypych, F.; Hirata, G.A.; Arizaga, G.G.C. Phosphor dysprosium-doped layered double hydroxides exchanged with different organic functional groups. $J$. Nanomater, 2013, Art. No. 730153.

[22] Tamboli, A.H.; Jadhav, A.R.; Chung, W.J.; Kim, H. Catalyst for hydrogen production from sodium borohydride hydrolysis Energy. Energy, 2015, 93, 955-962.

[23] Brinker, C.J.; Sherer, G.W. The Physics and Chemistry of Sol-Gel Processing. Academic Press, San Diego, 1990.

[24] Brinker C.J.; Sherer G.W. The Physics and Chemistry of Sol-Gel Processing. Academic Press, San Diego, 1990.

[25] Kareiva, A. Aqueous sol-gel synthesis methods for the preparation of garnet crystal structure compounds. Mater. Sci. (Medžiagotyra), 2011, 17, 428-437.

[26] Li, T.; He, H.F.; Zhang, T.; Zhao, B.; Chen, Z.Q.; Dai, H.Y.; Xue, R.Z.; Chen, Z.P. Effect of synthesizing temperatures on the microstructure and electrical property of $\mathrm{CaCu}_{3} \mathrm{Ti}_{4} \mathrm{O}_{12}$ ceramics prepared by sol-gel process. J. All Compd., 2016, 684, 315-321.

[27] Skruodiene, M.; Misevicius, M.; Sakalauskaite, M.; Katelnikovas, A.; Skaudzius, R. Doping effect of $\mathrm{Tb}^{3+}$ ions on luminescence properties of $\mathrm{Y}_{3} \mathrm{Al}_{5} \mathrm{O}_{12}: \mathrm{Cr}^{3+}$ phosphor. J. Lumin., 2016, 179, 355360 .

[28] Kloprogge, J.T.; Frost, R.L. Infrared and Raman spectroscopic studies of layered double hydroxides (LDHs). Nova Sci. Pub. Inc New York, 2001, 139-192.

[29] Posati, T.; Bellezza, F.; Cipiciani, A.; Costantino, F.; Nocchetti, M.; Tarpani, L.; Latterini, L. Synthesis and characterization of luminescent nanoclays. Cryst. Growth Des., 2010, 10, 2847-2850.

[30] Gago, S.; Pillinger, M.; Ferreira, R.A.S.; Carlos, L.D.; Santos, T.M.; Goncalves, I.S. Immobilization of lanthanide ions in a pillared layered double hydroxide. $\mathrm{PhD}$ Thesis, Chem. Mater., 2005, 5803-5809. 